\title{
Primordial follicle survival of goat ovarian tissue after vitrification and transplantation on chorioallanthoic membrane
}

\author{
Shofwal Widad ${ }^{1,2}$, Detty Siti Nurdiati ${ }^{2}$, Sarrah Ayuandari ${ }^{2}$, Kuky Cahya Hamurajib ${ }^{1,2}$, \\ Muhammad Dimas Reza Rahmana ${ }^{3}$, Nurulita Ainun Alma ${ }^{1,2}$ and Agung Dewanto ${ }^{1,2^{*}}$
}

\begin{abstract}
Background: Ovarian tissue vitrification is an alternative fertility preservation procedure for young female patients prior to gonadotoxic treatment. Primordial follicle loss might be a potential issue for vitrification and transplantation procedures. This study aimed to evaluate primordial follicle density and deoxyribonucleic acid (DNA) fragmentation in each stage of the preservation procedure of goat ovarian tissue. Follicle density and DNA fragmentation were examined microscopically after staining with hematoxylin eosin and TUNEL assay, respectively. Both parameters were compared between fresh, fresh-transplanted, vitrification, and vitrification-transplanted groups.

Results: A significant decrease was observed in the primordial follicle proportion after vitrification and transplantation compared to the primordial follicle proportion in the fresh group (88.09\% vs $52.42 \%, p<0.05,95 \%$ $\mathrm{Cl} 11.54,66.94)$. There was no significant difference in DNA fragmentations of primordial follicles between each group $(p>0.05)$.

Conclusions: The vitrification and transplantation process of goat ovarian strips could cause the primordial follicles loss and DNA damage of the follicles. However, primordial follicles loss and DNA damage were not significantly different in each procedure.
\end{abstract}

Keywords: Ovarian tissue, Vitrification, Transplantation, Primordial follicles loss, DNA fragmentation

\section{Background}

Cryopreservation has become a promising method for fertility preservation in young female patients with cancer before chemotherapy and radiotherapy [1, 2]. Ovarian tissue cryopreservation is an alternative procedure beside embryo or oocyte cryopreservation for patients who are at risk from gonadotoxic therapy [3]. Collection of ovarian tissue can be performed without considering the menstrual cycle which can delay cancer treatment and is suitable for prepubertal girls [4].

\footnotetext{
* Correspondence: agung.dewanto@ugm.ac.id

${ }^{1}$ Fertility and Reproduction Endocrinology Division, Department of Obstetrics and Gynecology, Universitas Gadjah Mada-Dr. Sardjito Hospital, Yogyakarta 55281 , Indonesia

${ }^{2}$ Department of Obstetrics and Gynecology, Universitas Gadjah Mada-Dr. Sardjito Hospital, Yogyakarta 55281, Indonesia

Full list of author information is available at the end of the article
}

Ovarian tissue consists of heterogeneous cell components [5] while primordial follicles dominate $90 \%$ of ovarian follicles [6, 7]. During the preservation procedure, loss of primordial follicles can occur during the preparation, cryopreservation, and retransplantation steps. The number of viable primordial follicles is clinically essential for the development of preovulatory follicles and longevity of ovarian transplant after the cryopreservation procedure [8]. In the preparation step, primordial follicle loss occurs due to fragmentation of ovarian tissue which could disrupt Hippo signaling in granulosa cells through activation PI3K/Akt/mTORC1 pathway in oocytes [9-11]. Throughout transportation, ovarian fragments could develop ischemia which causes lactic acid accumulation, proteolysis, lipolysis, lipid peroxidation, and decreased intracellular $\mathrm{pH}$ [12]. During 
the course of cryopreservation procedure, primordial follicles are more tolerable than other growing follicles because of their slow metabolic rate [6, 7]. On the other hand, the number of viable primordial follicles might be decreased following the retransplantation procedure [8].

Isolated primordial follicles which are cryopreserved by the slow freezing method were found to be more vulnerable to cryodamage compared to the vitrification method [13]. There are several mechanisms that cause the detrimental effects of the freezing-thawing procedure on oocytes such as chromosomal misalignment, modification in reactive oxygen species (ROS) and DNA fragmentation. These changes might impair gene expression in oocytes or follicular cells, followed by the disruption of the oocyte's function [14]. Accordingly, in order to determine the effect of vitrification and transplantation on primordial follicles, analyses of DNA fragmentation and follicle density are needed. Currently in Indonesia, both slow freezing and vitrification are not commonly used due to limited infrastructure and experience. We chose vitrification because it needs shorter time to master the skills and perform the procedure, does not need advanced equipment, uses only a small amount of nitrogen, and involves lower cost [15]. For retransplantation of ovarian fragments, the chorioallanthoic membrane (CAM) model was used because that system is an intermediate stage between in vitro culture and animal experiments [16]. The CAM system can be considered as an interface between in vitro and in vivo models, especially in xenotransplantation techniques [16].

Goat ovaries have been used as an ovarian vitrification model for many years in fertility studies. Beside its availability, previous study showed goat ovaries resemble human ovaries in size and tissue composition [17], and have dense fibrous stroma and high primordial follicle density in the cortex [18]. This research is a preliminary study before conducting research in humans. Additionally, this study aimed to set up and try out the laboratory equipment and establish experimental protocols for the next phase of the research as well as for later implementation in clinical services.

\section{Methods}

\section{Experimental procedures}

\section{Tissue samples and transportation}

Sixteen ovaries from goats (Capra hircus) aged 9-13 months were obtained at a local slaughterhouse in Yogyakarta, Indonesia, during the period of September to November 2018. After the goats were slaughtered, ovaries were transported to the Laboratory of Physiology at the Faculty of Medicine, Public Health and Nursing, Universitas Gadjah Mada within $1 \mathrm{~h}$ using a sterile transport box which was filled with ice to maintain a stable temperature between 5 and $8{ }^{\circ} \mathrm{C}$. Transport medium was composed of 10\% M199, serum-substituted supplement (10\% SSS), $2 \%$ penicillin-streptomycin (10, $000 \mathrm{U} / \mathrm{mL}$ ) (Thermo Fisher Scientific) and 1\% fungizone (Thermo Fisher Scientific).

\section{Preparation of the ovarian tissue}

After ovarian tissue collection ( $n=16$ tissue samples), the ovarian medulla was dissected using small scissors (Orthotech, Palermo, Italia) to form an ovarian cortical strip. Ovarian cortical strips (1-2 mm thickness) were prepared and cut into a small size of $5 \times 5 \mathrm{~mm}$. The ovarian strips were divided equally into four groups: the fresh group (Fr), fresh-transplanted group (FrTr), vitrification group $(\mathrm{Vi})$, and vitrification-transplanted group (ViTr) (Fig. 1).

\section{Ovarian tissue vitrification-thawing and transplantation}

We developed the vitrification method based on modifications of the method described by Suzuki et al. in 2015 [19]. Ovarian cortical strips were washed in M199 medium (Thermo Fisher Scientific, MA, USA) supplemented with $20 \%$ SSS. Ovarian cortical strips were equilibrated in equilibrium solution (ES) I that consisted of M199 medium, 10\% ethylene glycol (EG, Wako Oure Chemical Industries, Tokyo, Japan) and 20\% SSS for 5 min. The second equilibration was done in ES II that consisted of M199 medium, 20\% EG, 20\% SSS for 5 min. Next, ovarian cortical strips were transferred into the vitrification solution which consisted of M199 medium, 35\% EG, polyvinylpyrrolidone (Sigma-Aldrich, St. Louis, MO, USA) for $15 \mathrm{~min}$. Then, ovarian cortical strips were loaded into the cryodevice (Ova Cryo device type M, Kitazato, Tokyo, Japan) and stored in liquid nitrogen $\left(-196{ }^{\circ} \mathrm{C}\right)$ until they were used. Ovarian cortical strips were successfully vitrified if the ovarian cortex strips appeared transparent [19].

For thawing, ovarian strips were transferred into the thawing solution that consisted of M199, 20\% SSS, and $0.8 \mathrm{~mol} / \mathrm{l}$ sucrose for $1 \mathrm{~min}$ on a warming plate set at 37 ${ }^{\circ} \mathrm{C}$. Next, ovarian strips were incubated in diluting solution that consisted of $20 \%$ SSS, $0.4 \mathrm{ml} / \mathrm{l}$ sucrose for 3 min, followed by incubation in the washing solution that consisted of M199 and 20\% SSS for 5 min and repeated twice. Then, the ovarian cortical strip was transplanted for 5 days in CAM of 5-day-old fertilized eggs which were incubated at $37{ }^{\circ} \mathrm{C}$ and $44 \%$ humidity. After 5 days transplanted, the ovarian cortical strips were harvested and loaded into paraformaldehyde for the next step.

\section{Histological observation of follicle density}

Ovarian strips from the four groups were fixed in 10\% formalin, embedded in paraffin wax, serially sectioned in $4 \mu \mathrm{m}$ thickness, stained with hematoxylin and eosin $(\mathrm{HE})$ and observed under light microscope with $\times 100$ 


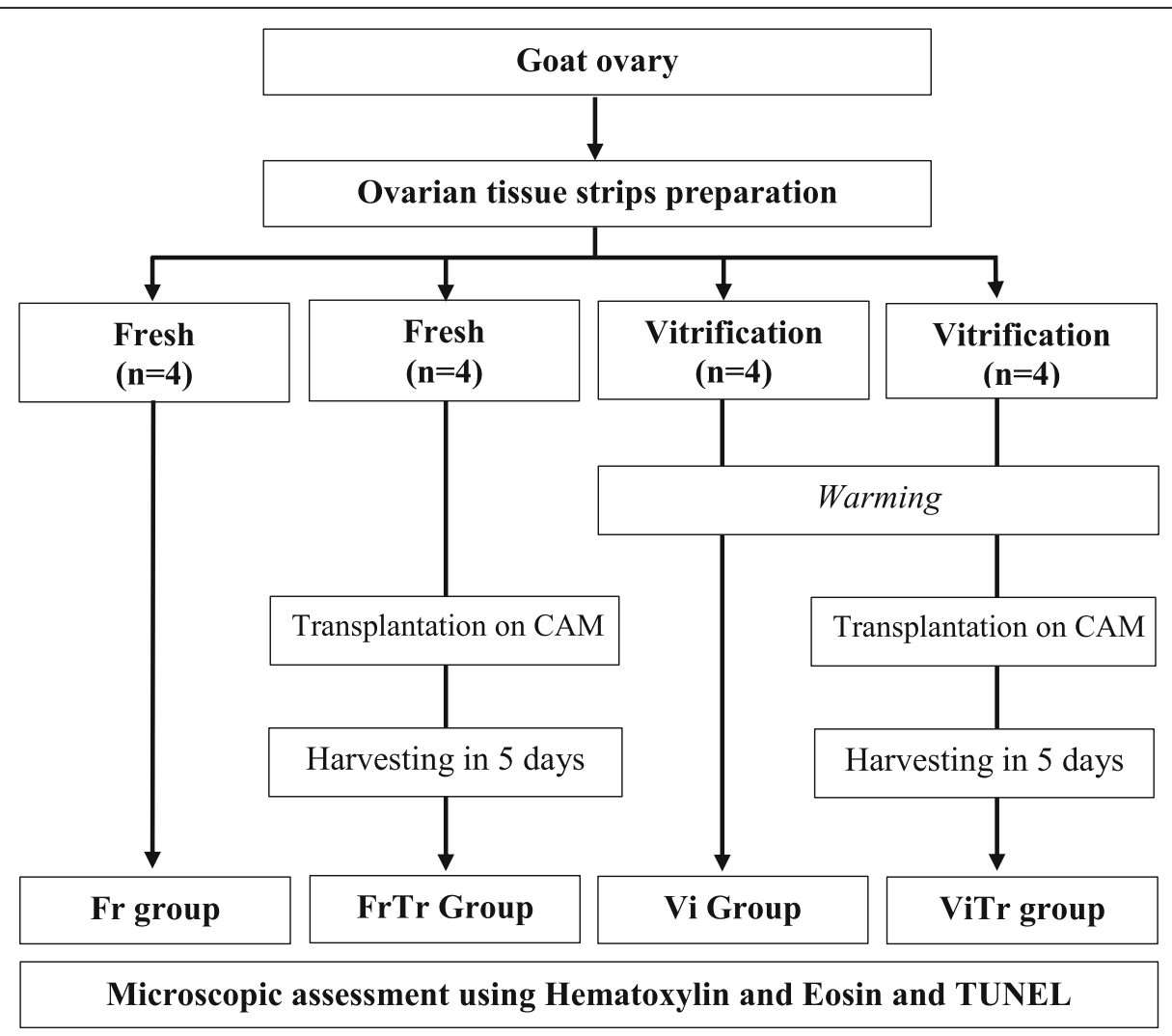

Fig. 1 Microscopic assessment using hematoxylin and eosin and TUNEL

and $\times 400$ magnification. Follicles were classified into two groups: primordial follicles which were surrounded by a single layer of flattened granulosa cells and growing follicles which have the appearance of one or more cuboidal granulosa cells surrounding them, which included primary, secondary, preantral, and antral follicles. Ovarian cortex strips were evaluated for their primordial follicle density which was defined as the number of healthy primordial follicles per total follicles from a random section from four ovarian strips in each group [20].

\section{DNA fragmentation assay}

The DNA fragmentation was assessed using an In Situ Cell Death Detection Kit (Roche, Germany). Paraffin sections were deparaffinized, rehydrated, and permeabilized with $20 \mu \mathrm{m}$ proteinase $\mathrm{K}$ in $10 \mathrm{mM}$ Tris $\mathrm{pH} 7.4$ (Qiagen, Netherlands). The washed slides were incubated with TdT-mediated dUTP-biotin nick-end labeling (TUNEL (Roche, Germany)) reagents according to the manufacturer's instructions and counterstained with methyl green. DNA fragmentation of primordial follicles was demonstrated by the presence of positive staining in $\geq 49 \%$ of granulosa cells [19]. DNA fragmentation of follicles was defined as the number of primordial follicles with positive TUNEL staining per total follicles from a random section from four ovarian strips in each group.

\section{Statistical analysis}

Statistical analysis was performed using SPSS 25.0 software (IBM Corp., Chicago). Follicular density and DNA fragmentation in the four groups were compared by one-way analysis of variance (ANOVA). Various characteristics were summarized by mean and standard deviation (SD) within groups. The level of statistical significance was set at $p<0.05$ with $95 \%$ confidence interval (CI).

\section{Results}

\section{Histological analysis}

Follicle density

In order to determine the effects of vitrification and transplantation of ovarian strips on the development of primordial follicles and DNA fragmentation, primordial follicles were counted after 5 days of incubation of the ovarian strips on CAM and analyzed histologically after HE staining (Fig. 2). Follicle density was assessed microscopically for primordial and growing follicles (Table 1).

In the Fr group, the percentage of primordial follicle was $88.09 \pm 9.62$. Compared to the FrTr group (86.93 \pm 
Fr group

a)

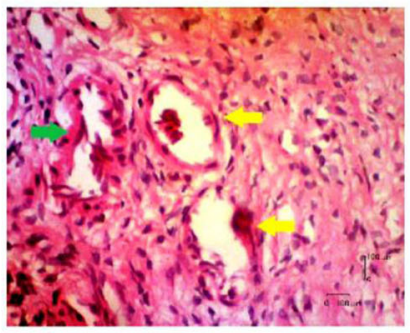

FrTr group

c)

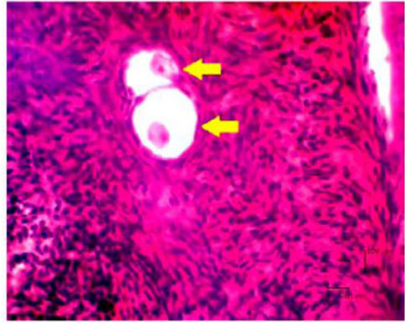

Vi group

e)

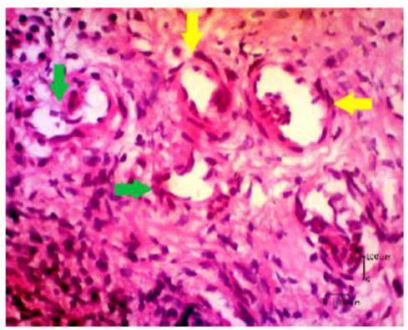

ViTr group

g)

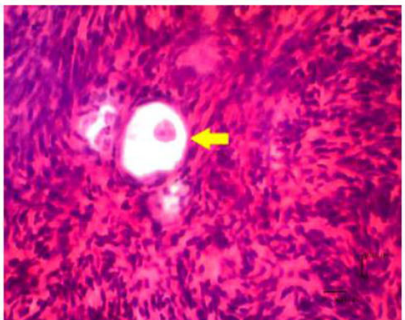

b)

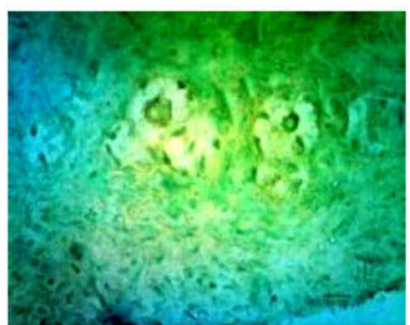

d)

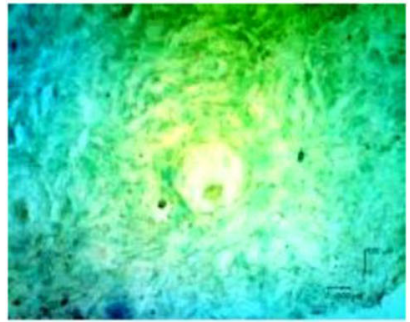

f)

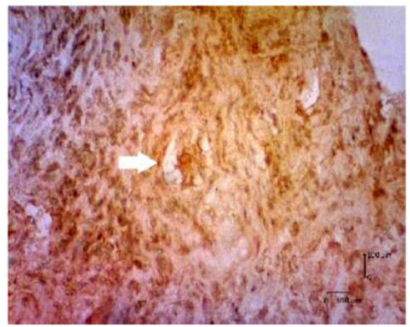

h)

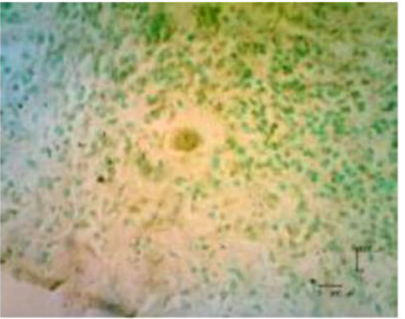

Fig. 2 Histological picture to determine healthy primordial follicles. Formalin-fixed paraffin-embedded goat ovarian tissues were stained for HE (a, $\mathbf{c}, \mathbf{e}, \mathbf{g}$ ) and TUNEL (b, d, $\mathbf{f}, \mathbf{h}$ ). Examination of HE observed both healthy primordial follicle cells (yellow arrows) and damaged primordial follicle cells with damage of membrane integrity or pyknotic cells (green arrows). In TUNEL staining, brown color primordial follicle cells show DNA fragmentation (white arrow). The proportion of primordial follicles in the fresh group was significantly higher compared to the vitrification group and vitrification and transplanted group $(p<0.05)$

15.11), the Fr group had higher density of primordial follicles although the result was not significant $(p=0.72$; $95 \%$ CI $-22.96,32.43)$. The same pattern was seen in the comparison between the Fr group and Vi group, where the density of the Fr group was not significantly higher $(p=0.09 ; 95 \% \mathrm{CI}-3.88,51.50)$ than the $\mathrm{Vi}$ group (67.85 \pm 27.00$)$ (Fig. 3).

After vitrification and thawing, the ovarian strips underwent transplantation on CAM for 5 days. In comparison, primordial follicle density in the $\mathrm{ViTr}$ group was significantly lower $(p<0.01 ; 95 \%$ CI 11.54 , 66.94) compared to the Fr group $(52.42 \pm 15.00$ vs $88.09 \pm 9.62$, respectively). However, primordial follicle density in the ViTr group was not significantly different $(p=0.25 ; 95 \%$ CI $12.26,43.12)$ from the $\mathrm{Vi}$ group $(67.85 \pm 27.00)$.

Meanwhile, during the incubation period, primordial follicle density was getting higher after the vitrification and/or transplantation procedure. The densities from the highest to the lowest were $\mathrm{ViTr}$ group 
Table 1 Proportions of viable primordial follicles, growing follicles and DNA fragmentation from fresh, fresh-transplanted, vitrification, and vitrified-transplanted groups

\begin{tabular}{llll}
\hline Groups & $\begin{array}{l}\text { Proportion of primordial } \\
\text { follicles (mean } \pm \text { SD) }\end{array}$ & $\begin{array}{l}\text { Proportion of growing follicles } \\
\text { (mean } \pm \text { SD) }\end{array}$ & $\begin{array}{l}\text { Proportion of DNA fragmentation } \\
\text { (mean } \pm \text { SD) }\end{array}$ \\
\hline Fresh (\%) & $88.09 \pm 8.01$ & $11.90 \pm 10.48$ & $52.08 \pm 19.02$ \\
Fresh-transplanted (\%) & $86.93 \pm 15.11$ & $13.06 \pm 15.11$ & $55.20 \pm 14.18$ \\
Vitrification (\%) & $67.85 \pm 27.00$ & $32.14 \pm 27.32$ & $65.00 \pm 23.80$ \\
Vitrified-transplanted (\%) & $52.42 \pm 15.00 *$ & $47.57 \pm 15.00^{*}$ & $60.13 \pm 10.71$ \\
\hline
\end{tabular}

DNA deoxyribonucleic acid, $S D$ standard deviation

${ }^{*} p<0.05$ compared to fresh group

$(47.57 \pm 15.00)$, Vi group $(32.14 \pm 27.32)$, FrTR group $(13.06 \pm 15.11)$, and Fr group $(11.90 \pm 10.48)$. Only the difference between the ViTr and the Fr group was significant $(p<0.01)$. The density of follicles was inversely proportional between primordial follicles and growing follicles within groups.

\section{DNA fragmentation}

The DNA fragmentation was examined using TUNEL assay. Proportions of DNA fragmentation of primordial follicles observed from the highest to the lowest were: the Vi group $(65.00 \pm 23.80)$, ViTr group $(60.13 \pm 10.71), \operatorname{Fr} T r$ group (55.20 \pm 14.18$)$, and Fr group (52.08 \pm 19.02$)$.

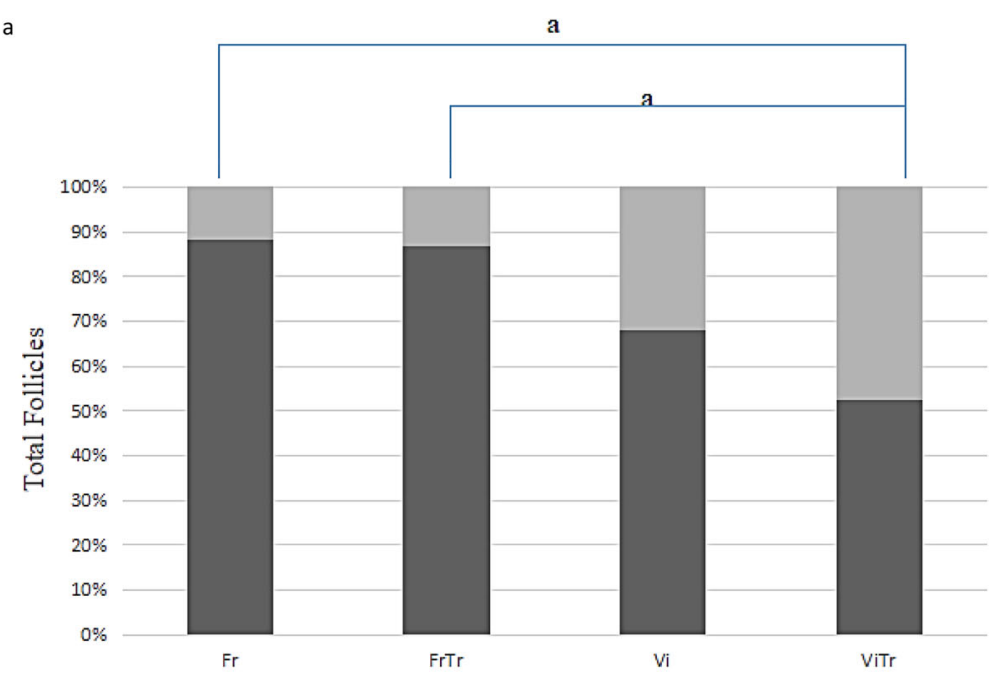

ㅁ Primordial Follicles $\square$ Growing Follicles

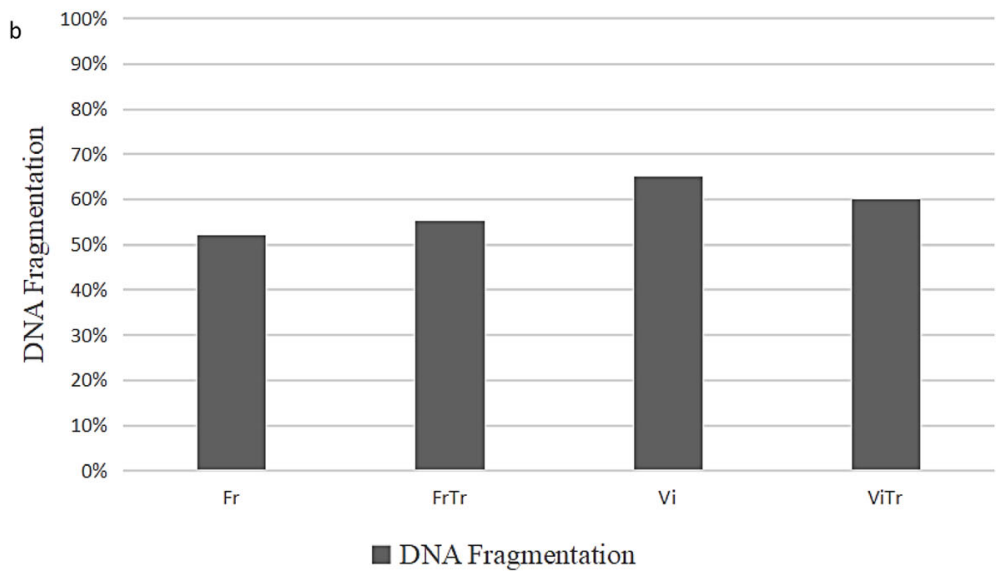

Fig. 3. Proportion of follicles and DNA fragmentation between groups. Comparison of primordial and growing follicle density showed for fresh (Fr), fresh-transplanted (FrTr), vitrification (Vi), and vitrification-transplanted (ViTr) group in a. DNA fragmentation analysis of follicle primordial using TUNEL assay (b). Statistically significant differences $(p<0.05)$ are indicated by letter $(\mathbf{a})$ 
However, the difference between groups was not significant $(p>0.05)$.

\section{Discussion}

The results of this study indicated a decrease in primordial follicle density at each stage of ovarian preservation. A decrease in primordial follicular density was associated with two main obstacles to ovarian tissue preservation, which were the presence of cryoinjury and ischemic tissue damage during transplantation procedures.

In this study, the cryoinjury process was assessed by comparing the Fr group and the Vi group. The density of primordial follicles in the Fr group was not significantly higher than the Vi group. This result was consistent with previous studies which showed no significant difference in primordial follicular density between the fresh and vitrified groups in female mice and bovine [21, 22]. Moreover, in human ovaries, primordial follicle density was significantly lower in the vitrification group than in the fresh group [23].

In the TUNEL analysis, DNA fragmentation in the $\mathrm{Fr}$ and Vi groups was not significantly different. From this parameter, a previous study which used dog ovaries did not find significant difference between follicular DNA fragmentation in the fresh and vitrified groups [24]. Conversely, another study obtained significant difference in follicular apoptosis between the vitrification group compared to the fresh group [21]. The increments of DNA fragmentation and primordial follicle loss in these groups might be related to cryoinjury which was correlated to cryodevice selection, modification of cryoprotective agents [25], and duration and temperature of transportation [26]. Apoptosis and tissue damage due to cyoinjury are thought to be related to increased expression of BAX and BCL2 in granulosa cells, oocytes, ovarian tissue stroma after vitrification, and warming [27]. The accumulation of BAX and BCL2 in mitochondria expresses cytochrome $C$ thereby increase caspase expression which induces cell death [28].

Decreased primordial follicle density was observed in the FrTr group compared to the Fr group. This decrease might be caused by ischemic injury through the transplantation process. This result was similar to a previous study which showed follicle decrease after the transplantation procedure although the finding was not statistically significant [21]. Other studies showed significant decrease of primordial follicles density after transplantation $[29,30]$. Ischemic condition occurs after transplantation and cause DNA damage due to reactive oxygen species (ROS). ROS activation induce PTEN inhibition which increase Akt phosphorylation (p-Akt). An increase in p-Akt lead to disruption of DNA damage response resulting in BAX accumulation in cell mitochondria and initiates apoptosis process [31].
In addition, the ViTr group had a primordial follicle density which was lower compared to the Vi group. The previous study found no significant difference in ovarian tissue between the vitrified and vitrified-transplant groups on the seventh day. However, the same study showed significant decrease in primordial follicle density [21].

In the DNA fragmentation parameter, there were no significant differences between the $\mathrm{Fr}$ and $\mathrm{FrTr}$ groups and between the Vi and ViTr groups. This result contradicted the previous study which found incremental DNA fragmentation in the fresh tissue group transplanted for 7 days compared to fresh group without transplantation. However, vitrified ovarian tissue which was transplanted had the same DNA fragmentation compared to the vitrified group without transplantation [21].

Our study showed no significant decrease in primordial follicle density and DNA fragmentation. However, other studies showed different results and the results are controversial. This difference in findings might be due to differences in cryodevices, cryoprotectant agents, duration, and transplantation techniques.

\section{Conclusions}

We concluded that the vitrification and transplantation process of goat ovarian strips could cause the primordial follicle loss and DNA fragmentation of the follicles. However, primordial follicle loss and DNA fragmentation were not significantly different in each procedure.

\section{Abbreviations}

DNA: Deoxyribonucleic acid; ROS: Reactive oxygen species; CAM: Chorioallanthoic membrane; SSS: Serum substituted supplement; Fr: Fresh group; FrTr: Fresh-transplanted group; Vi: Vitrification group; ViTr: Vitrification-transplanted group; ES: Equilibrium solution; EG: Ethylene glycol; HE: Hematoxylin and eosin; SD: Standard deviation

\section{Acknowledgements}

The authors thank the Department of Physiology and Department of Histology, Faculty of Medicine, Public Health and Nursing, Universitas Gadjah Mada, Yogyakarta, Indonesia, for technical assistance.

\section{Authors' contributions}

SW was involved in the study design, data interpretation, manuscript writing and review; DN was involved in the study design and manuscript review; SA contributed to data interpretation, manuscript review, and editing; KH was involved in the laboratory analysis, data analysis, manuscript writing and editing; MR was involved in the laboratory analysis and data analysis; NA was involved in the laboratory analysis, manuscript writing, and editing; AD was involved in the study design, data interpretation, and manuscript review. All authors have read and approved the final version of the manuscript.

\section{Funding}

This study did not receive any funding from public, commercial, or nonprofit sectors.

\section{Availability of data and materials}

Data findings are available from corresponding author upon reasonable request.

Ethics approval and consent to participate

The Medical and Health Research Ethics Committee from the Faculty of Medicine, Public Health, and Nursing, Universitas Gadjah Mada, Indonesia, 
approved all animal procedures in this study with the registration number KE/FK/1300/EC/2017.

\section{Consent for publication}

Not applicable.

\section{Competing interests}

All authors declare that they have no competing interests.

\section{Author details}

${ }^{1}$ Fertility and Reproduction Endocrinology Division, Department of Obstetrics and Gynecology, Universitas Gadjah Mada-Dr. Sardjito Hospital, Yogyakarta 55281, Indonesia. ${ }^{2}$ Department of Obstetrics and Gynecology, Universitas Gadjah Mada-Dr. Sardjito Hospital, Yogyakarta 55281, Indonesia. ${ }^{3}$ Biomedical Science Postgraduate Program, Faculty of Medicine, Public Health and Nursing, Universitas Gadjah Mada, Yogyakarta 55281, Indonesia.

Received: 2 August 2020 Accepted: 19 October 2020

Published online: 31 October 2020

\section{References}

1. Aubard Y, Poirot C, Piver P, Galinat S, Teissier MP (2001) Are there indications for ovarian tissue cryopreservation? Fertil Steril 76:414-415

2. Marci $R$, Mallozzi M, Di Benedetto $L$ et al (2018) Radiations and female fertility. Reprod Biol Endocrinol 16(1):112. https://doi.org/10.1186/s12958018-0432-0

3. Andersen CY, Kristensen SG, Greve T, Schmidt KT (2012) Cryopreservation of ovarian tissue for fertility preservation in young female oncological patients. Future Oncol 8:595-608

4. Posillico S, Kader A, Falcone T, Agarwal A (2010) Ovarian tissue vitrification: modalities, challenges and potentials. Curr Womens Health Rev 6:352-366

5. Hasegawa A, Hamada Y, Mehandjiev T, Koyama K (2004) In vitro growth and maturation as well as fertilization of mouse preantral oocytes from vitrified ovaries. Fertil Steril 81:824-830

6. Shaw JM, Cox SL, Trounson AO, Jenkin G (2000) Evaluation of the long-term function of cryopreserved ovarian grafts in the mouse, implications for human applications. Mol Cell Endocrinol 161:103-110

7. Shaw JM, Oranratnachai A, Trounson AO (2000) Fundamental cryobiology of mammalian oocytes and ovarian tissue. Theriogenology 53:59-72

8. Schmidt KLT, Ernst E, Byskov AG, Andersen AN, Andersen CY (2003) Survival of primordial follicles following prolonged transportation of ovarian tissue prior to cryopreservation. Hum Reprod 18(12):2654-2659. https://doi.org/10. 1093/humrep/deg500

9. Pan L, Chen S, Weng C, Call G, Zhu D, Tang H (2007) Stem cell aging is controlled both intrinsically and extrinsically in the drosophila ovary. Cell Stem Cell 1:458-469. https://doi.org/10.1016/.jstem.2007.09.010

10. Grosbois J, Demeestere I (2018) Dynamics of PI3K and Hippo signaling pathways during in vitro human follicle activation. Hum Reprod 3(9):17051714. https://doi.org/10.1093/humrep/dey250

11. Lee HN, Chang EM (2019) Primordial follicle activation as new treatment for primary ovarian insufficiency. Clin Exp Reprod Med 46(2):43-49. https://doi. org/10.5653/cerm.2019.46.2.43

12. Guibert EE, Petrenko AY, Balaban CL, Somov AY, Rodriguez JV, Fuller BJ (2011) Organ preservation: current concepts and new strategies for the next decade. Transfus Med Hemother 38:125-142. https://doi.org/10.1159/000327033

13. Desai N, AbdelHafez F, Ali MY, Sayed EH, Abu-Alhassan AM, Falcone T et al (2011) Mouse ovarian follicle cryopreservation using vitrification or slow programmed cooling: assessment of in vitro development, maturation, ultrastructure and meiotic spindle organization. J Obstet Gynecolog Res 37(1):1-12. https://doi.org/10.1111/j.1447-0756.2010.01215.x

14. Mathias FJ, D'souza F, Uppangala S, Salian SR, Kalthur G, Adiga SK (2014) Ovarian tissue vitrification is more efficient than slow freezing in protecting oocyte and granulosa cell DNA integrity. Syst Biol Reprod Med 60(6):317-322

15. Fahy G, MacFarlane D, Angell C, Meryman H (1984) Vitrification as an approach to cryopreservation. Cryobiology 21(4):407-426

16. Martinez-Madrid B, Donnez J, Eyck AV, Veiga-Lopez A, Dolmans M, Langendockt AV (2009) Chick embryo chorioallantoic membrane (CAM) model: a useful tool to study short-term transplantation of cryopreserved human ovarian tissue. Fertil Steril 91:285-292
17. Gosden RG, Baird DT, Wade JC, Webb R (1994) Restoration of fertility to oophorectomized sheep by ovarian autografts stored at $-196^{\circ} \mathrm{C}$. Hum Reprod 9:597-603

18. Oktay K, Karlikaya GG, Aydin BA (2000) Ovarian cryopreservation and transplantation: basic aspects. Mol Cell Endocrinol 169:105-108

19. Suzuki N, Yoshioka N, Takae S, Sughisita Y, Tamura M, Hashimoto Y et al (2015) Successful fertility preservation following ovarian tissue vitrification in patients with primary ovarian insufficiency. Hum Reprod 30:608-615

20. Masciangelo R, Hossay C, Donnez J, Dolmans M (2019) Does the Akt pathway play a role in follicle activation after grafting of human ovarian tissue? Reprod BioMed Online 39:196-198

21. Lee J, Kong HS, Kim EJ, Youm HW, Lee JR, Suh CS, Kim SH (2016) Ovarian injury during cryopreservation and transplantation in mice: a comparative study between cryoinjury and ischemic injury. Hum Reprod 31(8):18271837. https://doi.org/10.1093/humrep/dew144

22. Campos ALM, Guedes JS, Rodrigues JK, Pace WAP, Fontoura RR, Caetano JPJ et al (2016) Comparison between slow freezing and vitrification in terms of ovarian tissue viability in a bovine model. Rev Bras Ginecol Obstet 38(7): 333-339. https://doi.org/10.1055/s-0036-1586258

23. Oktem O, Alper E, Balaban B, Palaoglu E, Peker K, Karakaya C et al (2011) Vitrified human ovaries have fewer primordial follicles and produce less antiMüllerian hormone than slow-frozen ovaries. Fertil Steril 95(8):26612664.e1. https://doi.org/10.1016/j.fertnstert.2010.12.057

24. Hariya M, Suzuki H (2016) Incidence of apoptotic cells after vitrification in canine ovarian tissues. J Mammalian Ova Res 33(1):69-75. https://doi.org/10. 1274/jmor.33.69

25. Youm HW, Lee J, Kim EJ, Kong HS, Lee JR, Suh CS, Kim SH (2016) Effects of angiopoietin-2 on transplanted mouse ovarian tissue. PLoS One 11(11):1-13. https://doi.org/10.1371/journal.pone.0166782

26. Bos-Mikich A, Marques L, Rodrigues JL, Lothhammer N, Frantz N (2012) The use of a metal container for vitrification of mouse ovaries, as a clinical grade model for human ovarian tissue cryopreservation, after different times and temperatures of transport. J Assist Reprod Genet 29:1267-1271

27. Wiweko B, Andriyana $H$, Aulia A (2016) Ovarian tissue vitrification as a method for ovarian preservation in women with cancer: an analysis of granulose cell apoptosis. KnE Med 1(1):18-24

28. Nowsheen S, Yang ES (2012) The intersection between DNA damage response and cell death pathways. Exp Oncol 34(3):243-254

29. Liu J, Van Der Elst J, Van Den Broecke R, Dhont M (2002) Early massive follicle loss and apoptosis in heterotopically grafted newborn mouse ovaries. Hum Reprod 17(3):605-611. https://doi.org/10.1093/humrep/17.3.605

30. Nisolle M, Casanas-Roux F, Qu J, Motta P, Donnez J (2000) Histologic and ultrastructural evaluation of fresh and frozen-thawed human ovarian xenografts in nude mice. Fertil Steril 74(1):122-129. https://doi.org/10.1016/S0015-0282(00)00548-3

31. Maidarti M, Anderson RA, Telfer EE (2020) Crosstalk between PTEN/PI3K/Akt signalling and DNA damage in the oocyte: implications for primordial follicle activation, oocyte quality and ageing. Cells 9(1):200

\section{Publisher's Note}

Springer Nature remains neutral with regard to jurisdictional claims in published maps and institutional affiliations.

\section{Submit your manuscript to a SpringerOpen ${ }^{\circ}$ journal and benefit from:}

- Convenient online submission

- Rigorous peer review

- Open access: articles freely available online

High visibility within the field

- Retaining the copyright to your article

Submit your next manuscript at $>$ springeropen.com 